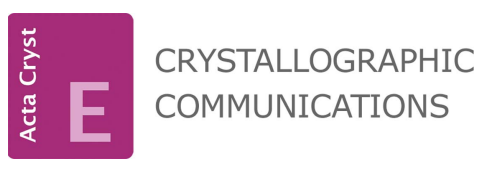

ISSN 2056-9890

Received 9 September 2019

Accepted 9 September 2019

Edited by W. T. A. Harrison, University of Aberdeen, Scotland

Keywords: crystal structure; thiourea; hydrogen bonding; Hirshfeld surface analysis; computational chemistry.

CCDC reference: 1919878

Supporting information: this article has supporting information at journals.iucr.org/e

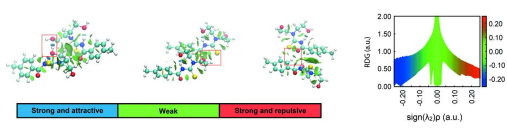

\section{3,3-Bis(2-hydroxyethyl)-1-(4-methylbenzoyl)thio- urea: crystal structure, Hirshfeld surface analysis and computational study}

\author{
Sang Loon Tan, ${ }^{\text {a }}$ Ainnul Hamidah Syahadah Azizan, ${ }^{a}$ Mukesh M. Jotani ${ }^{\mathrm{b}}$ and \\ Edward R. T. Tiekink ${ }^{\text {a* }}$
}

\begin{abstract}
a Research Centre for Crystalline Materials, School of Science and Technology, Sunway University, 47500 Bandar Sunway, Selangor Darul Ehsan, Malaysia, and 'bepartment of Physics, Bhavan's Sheth R. A. College of Science, Ahmedabad, Gujarat 380001, India. *Correspondence e-mail: edwardt@sunway.edu.my
\end{abstract}

In the title tri-substituted thiourea derivative, $\mathrm{C}_{13} \mathrm{H}_{18} \mathrm{~N}_{2} \mathrm{O}_{3} \mathrm{~S}$, the thione-S and carbonyl-O atoms lie, to a first approximation, to the same side of the molecule [the $\mathrm{S}-\mathrm{C}-\mathrm{N}-\mathrm{C}$ torsion angle is $-49.3(2)^{\circ}$ ]. The $\mathrm{CN}_{2} \mathrm{~S}$ plane is almost planar (r.m.s. deviation $=0.018 \AA$ ) with the hydroxyethyl groups lying to either side of this plane. One hydroxyethyl group is orientated towards the thioamide functionality enabling the formation of an intramolecular $\mathrm{N}-\mathrm{H} \cdots \mathrm{O}$ hydrogen bond leading to an $S(7)$ loop. The dihedral angle [72.12 (9) ${ }^{\circ}$ ] between the planes through the $\mathrm{CN}_{2} \mathrm{~S}$ atoms and the 4-tolyl ring indicates the molecule is twisted. The experimental molecular structure is close to the gas-phase, geometryoptimized structure calculated by DFT methods. In the molecular packing, hydroxyl-O $-\mathrm{H} \cdots \mathrm{O}$ (hydroxyl) and hydroxyl-O $-\mathrm{H} \cdots \mathrm{S}$ (thione) hydrogen bonds lead to the formation of a supramolecular layer in the $a b$ plane; no directional interactions are found between layers. The influence of the specified supramolecular interactions is apparent in the calculated Hirshfeld surfaces and these are shown to be attractive in non-covalent interaction plots; the interaction energies point to the important stabilization provided by directional $\mathrm{O}-\mathrm{H} \cdots \mathrm{O}$ hydrogen bonds.

\section{Chemical context}

The amine- $\mathrm{H}$ atoms in thiourea, $\mathrm{H}_{2} \mathrm{NC}(=\mathrm{S}) \mathrm{NH}_{2}$, can be systematically replaced to generate up to tetra-functionalized molecules, i.e. $R^{1}\left(R^{2}\right) \mathrm{NC}(=\mathrm{S}) \mathrm{N}\left(R^{3}\right) R^{4}$ for $R^{1-4}=$ alkyl/aryl. The present study concerns a tri-substituted example, i.e. an $N, N^{\prime}$-di(alkyl/aryl)- $N^{\prime}$-benzoylthiourea derivative, notable for having a carbonyl group connected to the thiourea framework. Thiourea molecules are of interest in themselves and as ligands for metal ions (Saeed et al., 2014). The free molecules, including benzoyl derivatives, are well-known to exhibit various biological properties, for example, anti-bacterial, antifungal and anti-viral activities as well as cytotoxicity (Hallur $e t$ al., 2006; Cunha et al., 2007; Saeed et al., 2010; Gunasekaran et al., 2017; Zhang et al., 2018; Gunasekaran, Ng et al., 2012). The combination of hard (oxygen) and soft (sulfur) donor atoms along with nitrogen suggests that benzoylthioureas can function as versatile ligands to metals. Indeed, a variety of coordination modes have been observed such as monodentate-S for the neutral ligand (Saeed et al., 2014; Gunasekaran, Ng et al., 2012). When deprotonated, a common mode of coordination is $\mathrm{O}-, \mathrm{S}$ - chelation with considerable delocalization of $\pi$ electron density over the ensuing six-membered chelate ring 
(Saeed et al., 2014). While the motivations for preparing metal complexes of benzoylthioureas are varied, e.g. for anion recognition and as catalysts (Saeed et al., 2014; Zhang \& Schreiner, 2009; Nishikawa, 2018), there is continuing interest in exploring their biological potential as coordination of these ligands to metals generally enhances their biological efficacy, such as anti-cancer (Peng et al., 2016; Barolli et al., 2017; Jeyalakshmi et al., 2019), anti-microbial (Gemili et al., 2017; Binzet et al., 2018; Saeed et al., 2018) and anti-mycobacterium tuberculosis (Plutín et al., 2016) activities. The present study was motivated by these applications and by previous structural studies (Gunasekaran et al., 2017; Selvakumaran \& Karvembu, et al., 2011; Selvakumaran, $\mathrm{Ng}$ et al., 2011) and the known catalytic applications of their cobalt complexes (Gunasekaran, Jerome et al., 2012). Herein, the synthesis, spectroscopic characterization and $\mathrm{X}$-ray crystallographic investigation of the title compound, 4- $\mathrm{MePhC}(=\mathrm{O}) \mathrm{N}(\mathrm{H}) \mathrm{C}(=\mathrm{S}) \mathrm{N}\left(\mathrm{CH}_{2^{-}}\right.$ $\left.\mathrm{CH}_{2} \mathrm{OH}\right)_{2}$, (I), are described, along with an analysis of the calculated Hirshfeld surfaces, non-covalent interaction plots as well as a computational chemistry study.<smiles>Cc1ccc(C(=O)NC(=S)N(CCO)CCO)cc1</smiles>

\section{Structural commentary}

The title compound, (I), is illustrated in Fig. 1, and selected interatomic parameters are given in Table 1 . The structure features a tri-substituted thiourea molecule with one $\mathrm{N}$ atom bearing a benzoyl residue and the other, carrying two hydroxyethyl groups. The thione-S and carbonyl-O atoms lie to the same side of the molecule but are only approximately syn as the $\mathrm{S} 1-\mathrm{C} 1-\mathrm{N} 2-\mathrm{C} 6$ torsion angle is $-49.3(2)^{\circ}$; the $\mathrm{O} 3-$ $\mathrm{C} 6-\mathrm{N} 2-\mathrm{C} 1$ torsion angle is $-6.8(3)^{\circ}$. The hydroxyethyl groups lie to either side of the $\mathrm{CN}_{2} \mathrm{~S}$ plane (r.m.s. deviation = $0.018 \AA$ ). The O1-hydroxyethyl group is folded toward the thioamide part of the molecule, an orientation that allows for the formation of an intramolecular $\mathrm{N} 2-\mathrm{H} \cdots \mathrm{O} 1$ hydrogen

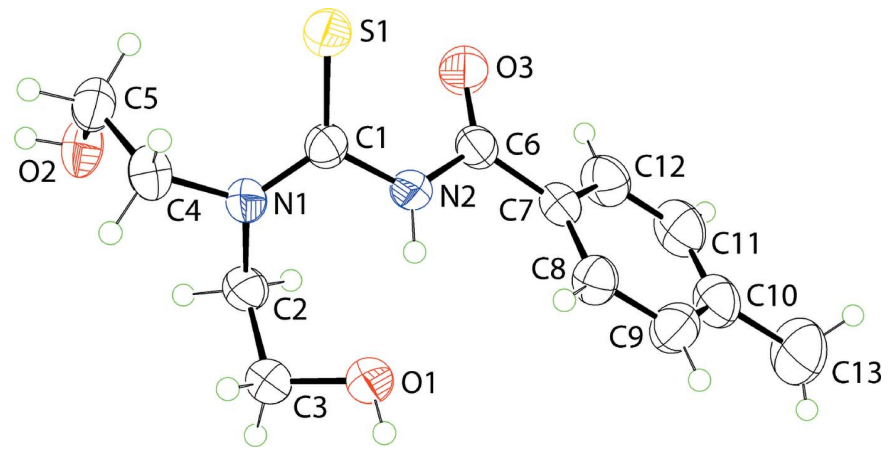

Figure 1

The molecular structure of (I) showing the atom-labelling scheme and displacement ellipsoids at the $50 \%$ probability level.
Table 1

Selected geometric parameters for (I) determined experimentally (X-ray) and from theory.

\begin{tabular}{lcr}
\hline Parameter & \multicolumn{1}{l}{ X-ray } & Theory \\
\hline C1-S1 & $1.6744(17)$ & 1.671 \\
C1-N1 & $1.335(2)$ & 1.368 \\
C1-N2 & $1.396(2)$ & 1.404 \\
C6-O3 & $1.214(2)$ & 1.220 \\
C6-N2 & $1.382(2)$ & 1.396 \\
S1-C1-N1 & $123.97(13)$ & 124.2 \\
S1-C1-N2 & $121.67(12)$ & 122.2 \\
N1-C1-N2 & $114.30(14)$ & 113.5 \\
O3-C6-N2 & $122.09(17)$ & 123.3 \\
O3-C6-C7 & $122.23(16)$ & 122.0 \\
N2-C6-C7 & $115.64(15)$ & 114.7 \\
S1-C1-N2-C6 & $-49.3(2)$ & -43.5 \\
S1-C1-N1-C2 & $171.63(12)$ & 167.1 \\
S1-C1-N1-C4 & $-7.3(2)$ & -7.6 \\
O3-C6-N2-C1 & $-6.8(3)$ & 18.2 \\
O3-C6-C7-C8 & $160.25(17)$ & -69.2 \\
N1-C2-C3-O1 & $-70.1(2)$ & 69.0 \\
N1-C4-C5-O2 & $57.5(2)$ &
\end{tabular}

Table 2

Hydrogen-bond geometry $\left(\AA{ }^{\circ}\right)$.

\begin{tabular}{lllll}
\hline$D-\mathrm{H} \cdots A$ & $D-\mathrm{H}$ & $\mathrm{H} \cdots A$ & $D \cdots A$ & $D-\mathrm{H} \cdots A$ \\
\hline $\mathrm{N} 2-\mathrm{H} 2 N \cdots \mathrm{O} 1$ & $0.87(1)$ & $1.91(1)$ & $2.728(2)$ & $157(1)$ \\
$\mathrm{O} 1-\mathrm{H} 1 O \cdots \mathrm{O} 2^{\mathrm{i}}$ & $0.83(2)$ & $1.94(2)$ & $2.769(2)$ & $172(2)$ \\
$\mathrm{O} 2-\mathrm{H} 2 O \cdots \mathrm{S} 1^{\mathrm{ii}}$ & $0.84(2)$ & $2.38(2)$ & $3.2049(14)$ & $171(2)$ \\
$\mathrm{C} 8-\mathrm{H} 8 \cdots \mathrm{O} 3^{\mathrm{iii}}$ & 0.93 & 2.38 & $3.251(2)$ & 156 \\
\hline
\end{tabular}

Symmetry codes: (i) $-x, y-\frac{1}{2},-z+\frac{1}{2}$; (ii) $x-1, y, z$; (iii) $-x+1, y-\frac{1}{2},-z+\frac{1}{2}$.

bond that closes an $S(7)$ loop, Table 2. Overall, the molecule is twisted as seen in the dihedral angle of $72.12(9)^{\circ}$ between the $\mathrm{CN}_{2} \mathrm{~S}$ atoms and the terminal aryl ring. The $\mathrm{C} 1-\mathrm{N} 1$ bond length is considerably shorter than the $\mathrm{C} 1-\mathrm{N} 2$ bond, which suggests some delocalization of $\pi$-electron density over the $\mathrm{S} 1-\mathrm{C} 1-\mathrm{N} 1$ atoms that does not extend over the $\mathrm{C} 1-\mathrm{N} 1-$ $\mathrm{C} 6$ atoms, consistent with the large twist about the $\mathrm{C} 1-\mathrm{N} 2$ bond (see above). The bond angles subtended at the $\mathrm{C} 1$ and C6 atoms follow the expected trends in that those involving the formally doubly bonded atoms are wider, by approximately $10^{\circ}$, compared with the other angles, Table 1.

\section{Gas-phase theoretical structure}

Compound (I) was subjected to gas-phase geometry optimization by long-range corrected wB97XD density functional with Grimme's D2 dispersion model (Chai \& Head-Gordon, 2008) coupled with Pople's 6-311+G $(d, p)$ basis set (Petersson et al., 1988) as implemented in Gaussian16 (Frisch et al., 2016) in order to compare the optimized molecule with the experimental structure. The results of the optimization show that the local minimum structure in the gas-phase was located as confirmed through a frequency analysis with zero imaginary frequency. The superimposition of the experimental and theoretical structures (Macrae et al., 2006), Fig. 2, indicates that there are minor differences between the molecules in either phase, with the r.m.s. deviation between them being 


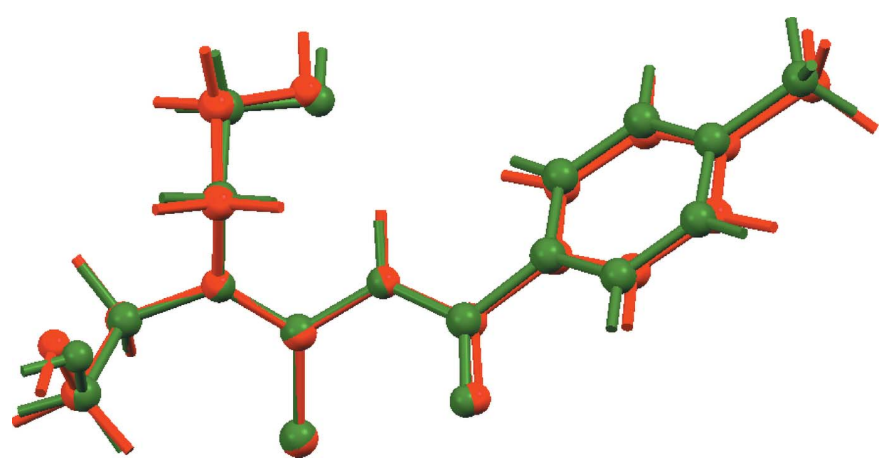

Figure 2

Overlay diagram for experimental (green image) and geometryoptimized (red) molecules for (I). The molecules have been overlapped so the $\mathrm{S}=\mathrm{C}-\mathrm{N}-\mathrm{C}=\mathrm{O}$ fragments are coincident.

$0.014 \AA$ A. Salient geometric data for the gas-phase structure are included in Table 1 and correlate very well with the experimental results. The major differences between the experimental and geometry-optimized structures relates to
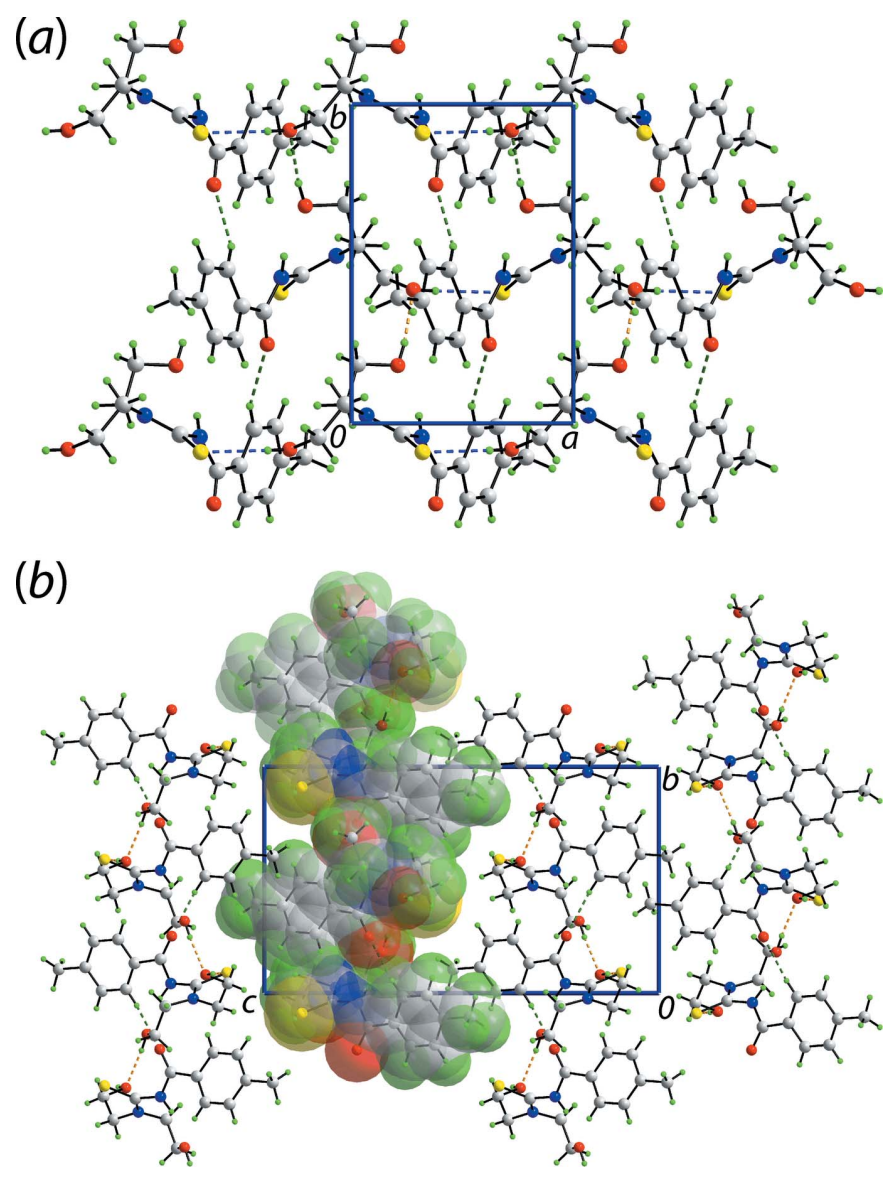

Figure 3

Views of the molecular packing in (I): (a) supramolecular layer in the $a b$ plane sustained by hydroxy-O-H $\cdots \mathrm{O}$ (hydroxy), hydroxy-O$\mathrm{H} \cdots \mathrm{S}$ (thione) and aryl- $\mathrm{C}-\mathrm{H} \cdots \mathrm{O}$ (carbonyl) interactions, and (b) view of the unit-cell contents in projection down the $a$ axis, highlighting the stacking of layers; one layer is represented in space-filling mode. The $\mathrm{O}-$ $\mathrm{H} \cdots \mathrm{O}, \mathrm{O}-\mathrm{H} \cdots \mathrm{S}$ and $\mathrm{C}-\mathrm{H} \cdots \mathrm{O}$ interactions are shown as orange, blue and green dashed lines, respectively. differences in the (i) $\mathrm{O} 3-\mathrm{C} 6-\mathrm{N} 2-\mathrm{C} 1$ torsion angles, which deviates further, by approximately $10^{\circ}$, from the anti-disposition in the optimized structure, and (ii) $\mathrm{N} 1-\mathrm{C} 2-\mathrm{C} 3-\mathrm{O} 1$ and $\mathrm{N} 1-\mathrm{C} 4-\mathrm{C} 5-\mathrm{O} 2$ torsion angles, which are disparate, by about $12^{\circ}$, in the experimental structure but are symmetric, i.e. $\pm 69^{\circ}$, in the optimized structure.

\section{Supramolecular features}

In the crystal of (I), the O1-hydroxyl group acts as a hydrogenbond donor to the $\mathrm{O} 2$-hydroxy group, which in turn functions as a donor to the S1-atom, Table 2. The $\mathrm{O}-\mathrm{H} \cdots \mathrm{O}$ hydrogen bonding is propagated by $2_{1}$ symmetry to generate helical chains along the $b$-axis direction. The $\mathrm{O}-\mathrm{H} \cdots \mathrm{S}$ hydrogen bonding serves to connect translationally related chains along the $a$-axis direction and these contacts are reinforced by phenyl-C-H..O(carbonyl) interactions. In this way, a supramolecular layer in the $a b$ plane is formed, Fig. 3(a). Layers stack along the $c$-axis direction without directional interactions between them, Fig. 3(b).

\section{Hirshfeld surface analysis}

The calculations of the Hirshfeld surfaces and the twodimensional fingerprint plots (overall and delineated) for (I) were performed using Crystal Explorer 17 (Turner et al., 2017) and published protocols (Tan et al., 2019).

The Hirshfeld surface mapped over electrostatic potential in Fig. 4, shows different potentials surrounding the key functional groups. Thus, the donors and acceptors of conventional $\mathrm{O}-\mathrm{H} \cdots \mathrm{O}$ and $\mathrm{O}-\mathrm{H} \cdots \mathrm{S}$ hydrogen bonds and $\mathrm{C}-\mathrm{H} \cdots \mathrm{O}$ contacts appear as blue and red regions, respectively, corresponding to positive and negative potential. The Hirshfeld surface mapped over $d_{\text {norm }}$ in Fig. 5 also gives the usual indications of these intermolecular interactions through the appearance of bright-red spots near participating atoms. In addition, short interatomic contacts between the hydroxyl-H atom, and carbonyl-C6 and hydroxyl-O2 atoms, and between the ethyl-C5 and hydroxyl-H1O atoms, Table 3, are either

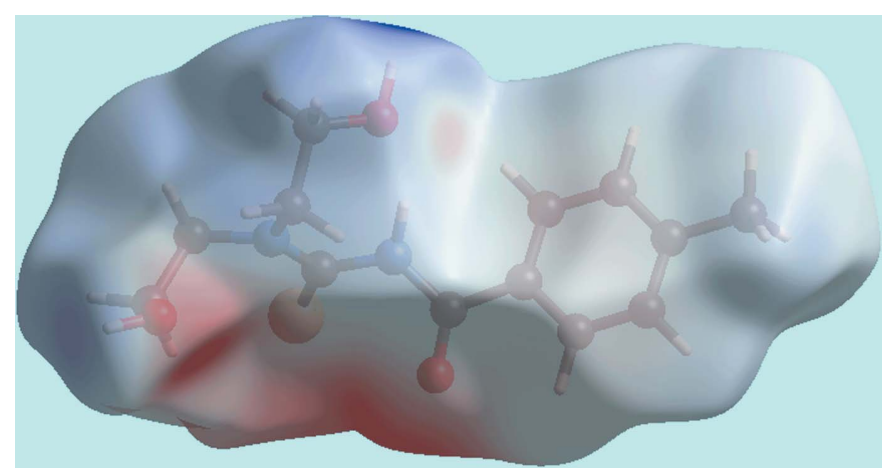

Figure 4

A view of the Hirshfeld surface mapped over the calculated electrostatic potential for (I). The red and blue regions represent negative and positive electrostatic potentials, respectively. The potentials were calculated using the STO-3G basis set at Hartree-Fock level of theory over a range of \pm 0.18 atomic units. 


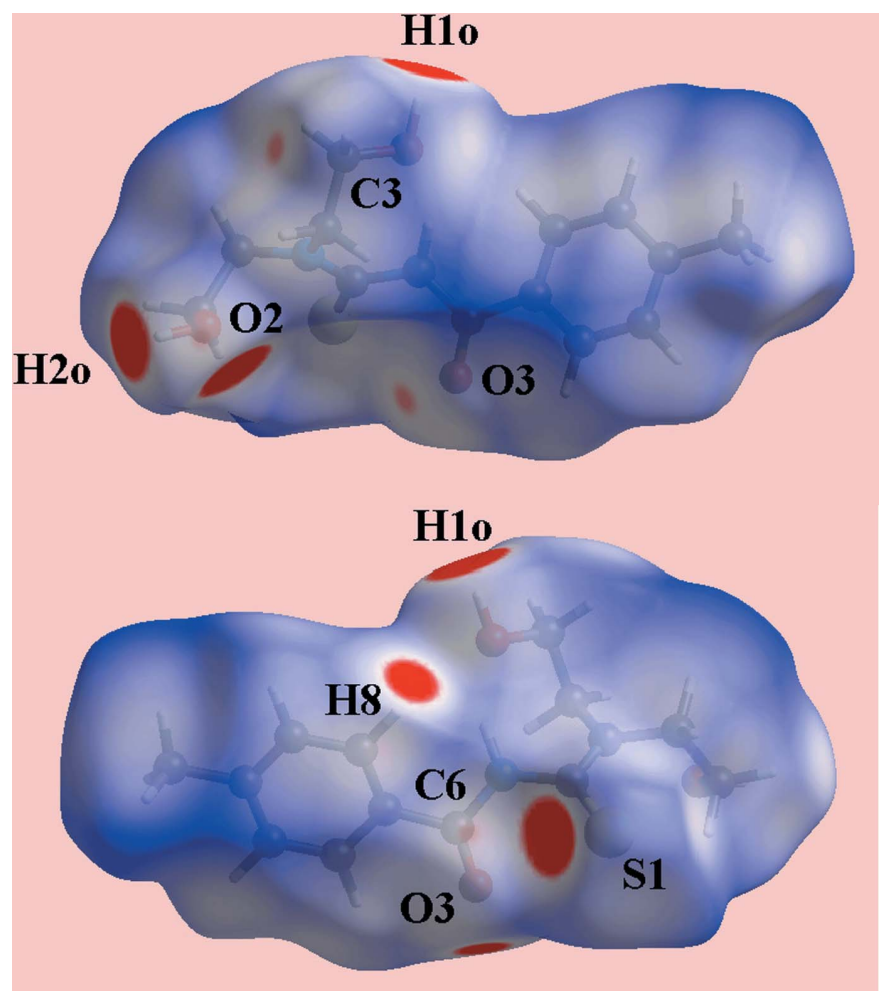

Figure 5

Two views of the Hirshfeld surface mapped over $d_{\text {norm }}$ for (I) in the range -0.132 to +1.682 arbitrary units

characterized as faint-red spots or merged within the brightred spots corresponding to the conventional hydrogen bonds in Fig. 5.

The intermolecular contacts in the crystal of (I) were further analysed using an enrichment ratio $(E R)$ descriptor, which is derived from the analysis of the Hirshfeld surface (Jelsch et al., 2014). The ER relates the propensity of pair of chemical species to form a specific interaction in a crystal. The enrichment ratio, $E R(X, Y)$, for a pair of elements $(X, Y)$ is defined as the ratio between proportion of actual contacts in the crystal to the theoretical proportion of random contacts. This ratio is greater than unity for a pair of elements having a high likelihood to form contacts in a crystal, while it is less than one for a pair which tends to avoid contacts with each other. A listing of $E R$ values for (I) is given in Table 4. The enrichment ratios greater than unity for the atom pairs $(\mathrm{O}, \mathrm{H})$
Table 3

Summary of short interatomic contacts $(\AA)$ in (I).

The interatomic distances are calculated in Crystal Explorer 17 (Turner et al., 2017) whereby the $X-\mathrm{H}$ bond lengths are adjusted to their neutron values.

\begin{tabular}{lll}
\hline Contact & Distance & Symmetry operation \\
\hline $\mathrm{H} 1 O \cdots \mathrm{H} 2 O$ & 2.26 & $-x,-\frac{1}{2}+y,-\frac{1}{2}-z$ \\
$\mathrm{C} 3 \cdots \mathrm{O} 3$ & $3.112(2)$ & $-x,-\frac{1}{2}+y, \frac{1}{2}-z$ \\
$\mathrm{H} 2 B \cdots \mathrm{O} 3$ & 2.58 & $-x,-\frac{1}{2}+y, \frac{1}{2}-z$ \\
$\mathrm{H} 3 B \cdots \mathrm{O} 3$ & 2.69 & $-x,-\frac{1}{2}+y, \frac{1}{2}-z$ \\
$\mathrm{C} 5 \cdots \mathrm{H} 1 O$ & 2.73 & $-x,-\frac{1}{2}+y, \frac{1}{2}-z$ \\
$\mathrm{H} 13 A \cdots \mathrm{O} 1$ & 2.67 & $1-x, 1-y,-z$ \\
$\mathrm{C} 6 \cdots \mathrm{O} 2$ & $3.177(2)$ & $1+x, y, z$ \\
$\mathrm{C} 8 \cdots \mathrm{H} 2 B$ & 2.78 & $1+x, y, z$ \\
\hline
\end{tabular}

Table 4

Enrichment ratios for (I).

\begin{tabular}{ll}
\hline Parameter & Ratio \\
\hline $\mathrm{H} \cdots \mathrm{H}$ & 0.92 \\
$\mathrm{C} \cdots \mathrm{H}$ & 1.21 \\
$\mathrm{O} \cdots \mathrm{H}$ & 1.21 \\
$\mathrm{~S} \cdots \mathrm{H}$ & 1.33 \\
$\mathrm{C} \cdots \mathrm{O}$ & 0.54 \\
\hline
\end{tabular}

Table 5

Percentage contributions of interatomic contacts to the Hirshfeld surface for (I).

\begin{tabular}{ll}
\hline Contact & Percentage contribution \\
\hline $\mathrm{H} \cdots \mathrm{H}$ & 52.5 \\
$\mathrm{C} \cdots \mathrm{H} / \mathrm{H} \cdots \mathrm{C}$ & 16.2 \\
$\mathrm{O} \cdots \mathrm{H} / \mathrm{H} \cdots \mathrm{O}$ & 15.0 \\
$\mathrm{~S} \cdots \mathrm{H} / \mathrm{H} \cdots \mathrm{S}$ & 13.1 \\
$\mathrm{~N} \cdots \mathrm{H} / \mathrm{H} \cdots \mathrm{N}$ & 1.5 \\
$\mathrm{C} \cdots \mathrm{C}$ & 0.3 \\
$\mathrm{C} \cdots \mathrm{O} / \mathrm{O} \cdots \mathrm{C}$ & 0.8 \\
$\mathrm{~N} \cdots \mathrm{O} / \mathrm{O} \cdots \mathrm{N}$ & 0.1 \\
$\mathrm{O} \cdots \mathrm{O}$ & 0.3 \\
$\mathrm{C} \cdots \mathrm{N} / \mathrm{N} \cdots \mathrm{C}$ & 0.2 \\
\hline
\end{tabular}

and $(\mathrm{S}, \mathrm{H})$, Table 4 , are consistent with the high propensity for the formation of the $\mathrm{O}-\mathrm{H} \cdots \mathrm{O}$ and $\mathrm{O}-\mathrm{H} \cdots \mathrm{S}$ hydrogen bonds in the crystal. It is also evident that the value greater than unity for $(\mathrm{C}, \mathrm{H})$ arises from the $\mathrm{C} \cdot \mathrm{H} / \mathrm{H} \cdots \mathrm{C}$ contacts.

The overall fingerprint plots for (I) and those delineated into $\mathrm{H} \cdots \mathrm{H}, \mathrm{O} \cdots \mathrm{H} / \mathrm{H} \cdots \mathrm{O}, \mathrm{C} \cdot \mathrm{H} / \mathrm{H} \cdots \mathrm{C}$ and $\mathrm{S} \cdots \mathrm{H} / \mathrm{H} \cdots \mathrm{S}$ contacts are illustrated in Fig. 6(a)-(e), respectively. A summary of the percentage contributions from the various contacts in the crystal are given in Table 5. The contribution (a)

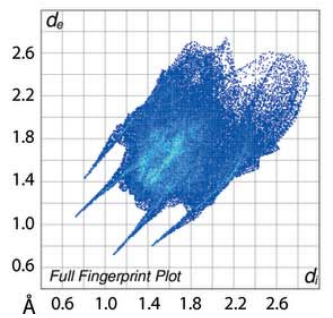

(b)

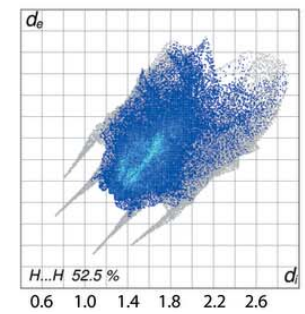

(c)

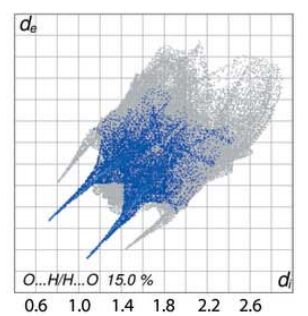

(d)

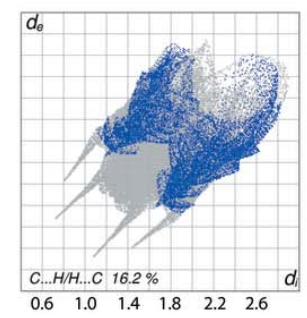

(e)

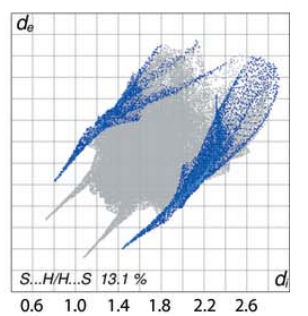

Figure 6

(a) A comparison of the full two-dimensional fingerprint plot for (I) and those delineated into $(b) \mathrm{H} \cdots \mathrm{H},(c) \mathrm{O} \cdots \mathrm{H} / \mathrm{H} \cdots \mathrm{O},(d) \mathrm{C} \cdots \mathrm{H} / \mathrm{H} \cdots \mathrm{C}$ and $(e)$ $\mathrm{S} \cdots \mathrm{H} / \mathrm{H} \cdots \mathrm{S}$ contacts. 
Table 6

Summary of interaction energies $\left(\mathrm{kcal} \mathrm{mol}^{-1}\right)$ calculated for several directional contacts in (I).

\begin{tabular}{ll}
\hline Contact & $E_{\text {tot }}$ \\
\hline $\mathrm{O} 1-\mathrm{H} 1 O \cdots \mathrm{O} 2$ & -14.52 \\
$\mathrm{O} 2-\mathrm{H} 2 O \cdots \mathrm{S} 1$ & -6.27 \\
$\mathrm{C} 8-\mathrm{H} 8 \cdots \mathrm{O} 3$ & -9.65 \\
\hline
\end{tabular}

from $\mathrm{H} \cdot \mathrm{H}$ contacts are reflected in the middle of the scattered point and cover the greatest area in the plot, and make the most significant contribution $(52.5 \%)$ to the total Hirshfeld surface, Fig. 6(b) and has an $E R$ value of 0.92 , i.e. close to unity. The contribution from $\mathrm{O} \cdots \mathrm{H} / \mathrm{H} \cdots \mathrm{O}$ contacts is viewed as long spikes at $d_{\mathrm{e}}+d_{\mathrm{i}} \sim 1.8 \AA$, with points scattered around different regions in the delineated fingerprint plot, Fig. 6(c). In the fingerprint delineated into $\mathrm{C} \cdots \mathrm{H} / \mathrm{H} \cdots \mathrm{C}$ contacts in Fig. $6(d)$, a pair of small tips at $d_{\mathrm{e}}+d_{\mathrm{i}}<2.8 \AA$ is the result of short interatomic contacts, Table 3 , including an interlayer contact $(\mathrm{H} 13 A \cdots \mathrm{O} 1)$. The percentage contribution from $\mathrm{S} \cdots \mathrm{H} / \mathrm{H} \cdots \mathrm{S}$ contacts $(13.1 \%)$ reflect the presence of $\mathrm{O}-$ $\mathrm{H}$...S hydrogen bonds and are apparent through the appearance of asymmetric spikes at $d_{\mathrm{e}}+d_{\mathrm{i}} \sim 2.1 \AA$ in Fig. $6(e)$.

\section{Computational chemistry}

The intermolecular $\mathrm{O}-\mathrm{H} \cdots \mathrm{O}, \mathrm{O}-\mathrm{H} \cdots \mathrm{S}$ and $\mathrm{C}-\mathrm{H} \cdots \mathrm{O}$ interactions occurring between the respective pairs of molecules were subjected to energy calculations by DFTwB97XD/aug-cc-pVTZ (Woon \& Dunning, 1993) for the evaluation of the strength of these interactions. With reference to the BSSE corrected interaction energies $\left(E_{\mathrm{int}}^{\mathrm{BSSE}}\right)$ listed in Table 6, the $\mathrm{O}-\mathrm{H} \cdots \mathrm{O}$ hydrogen bond has the greatest interaction energy, followed by $\mathrm{C}-\mathrm{H} \cdots \mathrm{O}$ and $\mathrm{O}-\mathrm{H} \cdots \mathrm{S}$. Unexpectedly, the $\mathrm{C}-\mathrm{H} \cdots \mathrm{O}$ interaction has an energy approximately 3-4 $\mathrm{kcal} \mathrm{mol}^{-1}$ more stable than the $\mathrm{O}-\mathrm{H} \cdots \mathrm{S}$ interaction despite phenyl- $\mathrm{C}-\mathrm{H}$ being a weak hydrogen-bond donor and thione-S a weak acceptor, and that such interactions are known to be dispersive in nature (Bhattacharyya $e t$ al., 2013). The donor-acceptor interactions were also evaluated by a natural bond orbital (NBO) population analysis (Reed et al., 1988), which revealed that the net NBO charge for $\mathrm{H} 8 \cdots \mathrm{O} 3$ is 0.8 compared to 0.6 for $\mathrm{H} 2 \mathrm{O} \cdots \mathrm{S} 1$, thereby confirming the relative strength of these interactions.

To complement the results of the calculations on the interaction energies, the dimeric structures were subjected to further analysis by NCIPLOT (Johnson et al., 2010). The analysis provides a convenient visualization index on the strength of any existing non-covalent interactions through a red-blue-green colour scheme on the isosurface, i.e. red is indicative of a strong repulsive interaction, blue is indicative of strong attractive interaction while green is indicative of a weak interaction (Contreras-García et al., 2011). The results, illustrated in Fig. 7, reveal that the $\mathrm{O}-\mathrm{H} \cdots \mathrm{O}$ interaction is clearly strong and attractive, while both $\mathrm{O}-\mathrm{H} \cdots \mathrm{S}$ and $\mathrm{C}-\mathrm{H} \cdots \mathrm{O}$ are considered weak interactions.

As the molecular packing is governed directionally by hydrogen bonding between molecules, the energy frameworks were simulated (Turner et al., 2017) in order to compare the topology of these intermolecular interactions. A detailed (a)

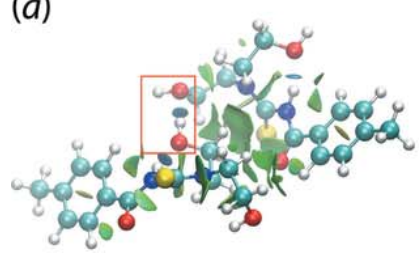

(b)

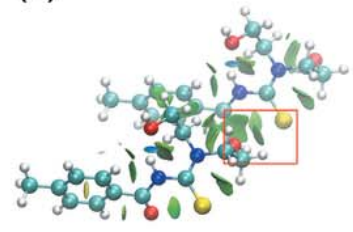

(c)

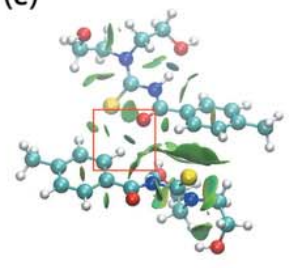

(d)

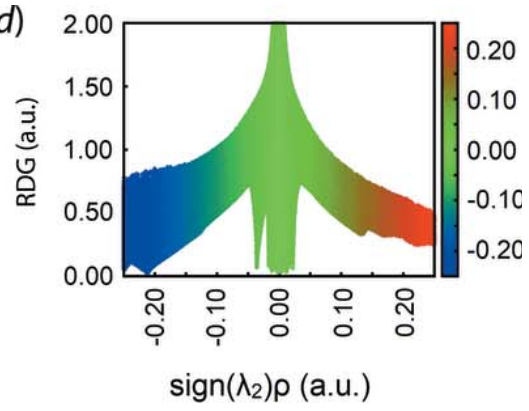

Figure 7

NCI plots for the dimeric aggregates in (I) sustained by $(a) \mathrm{O}-\mathrm{H} \cdots \mathrm{O},(b) \mathrm{O}-\mathrm{H} \cdots \mathrm{S}$ and $(c) \mathrm{C}-\mathrm{H} \cdots \mathrm{O}$ interactions (highlighted in boxes), and $(d)$ plot of RDG versus $\operatorname{sign}\left(\lambda_{2}\right) \rho(r)$. The gradient cut-off is set at 0.4 and the colour scale is $-0.03<\rho<0.03$ atomic units.

(a)

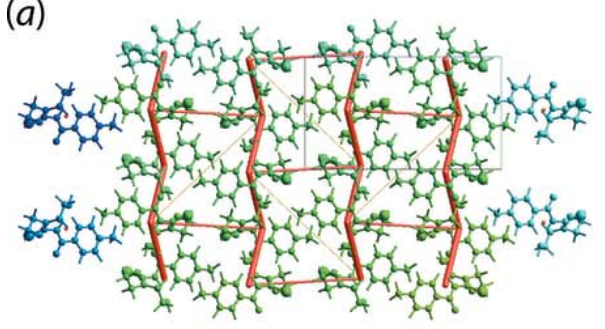

(b)

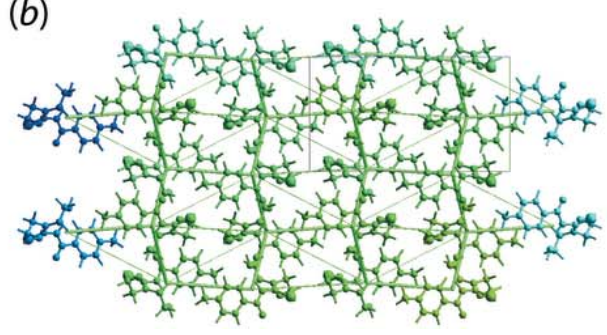

(c)

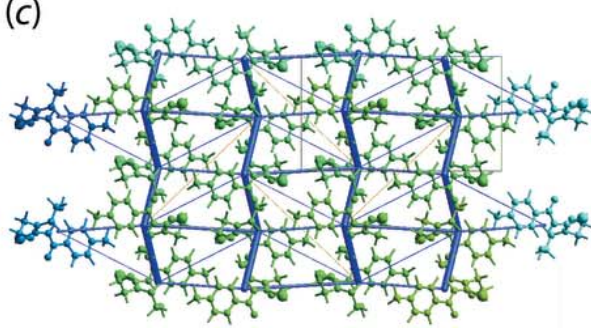

Figure 8

The energy framework diagrams for (I) showing $(a) E_{\text {electrostatic }}$ (red cylinders), (b) $E_{\text {dispersion }}$ (green cylinders) and (c) $E_{\text {total }}$ (blue cylinders), viewed along the $a$ axis. The frameworks were adjusted to the same scale factor of 50 with a cut-off value of $2.39 \mathrm{kcal} \mathrm{mol}^{-1}$ within $2 \times 2 \times 2$ unit cells. The corresponding cylinder radii are proportional to the relative magnitude of the energies. 
analysis of the energy frameworks shown in Fig. 8 reveals the crystal of (I) is mainly stabilized by electrostatic and dispersive forces. The total electrostatic energy ( $\left.E_{\text {electrostatic }}\right)$ of all pairwise interactions sums to $-36.11 \mathrm{kcal} \mathrm{mol}^{-1}$, while the total dispersion energy term $\left(E_{\text {dispersion }}\right)$ computes to $-43.83 \mathrm{kcal}$ $\mathrm{mol}^{-1}$.

\section{Database survey}

The crystal structure of the parent compound, $\mathrm{PhC}(=\mathrm{O}) \mathrm{N}(\mathrm{H}) \mathrm{C}(=\mathrm{S}) \mathrm{N}\left(\mathrm{CH}_{2} \mathrm{CH}_{2} \mathrm{OH}\right)_{2}, \quad$ (II), has been reported twice (Koch et al., 1995; Cornejo et al., 2005; refcodes ZAJWAI and ZAJWAI01, respectively). The conformation of this molecule and that of (I) are very similar and the geometric parameters describing chemically equivalent parameters are generally within experimental errors. The most important conformational difference is seen in the pair of $\mathrm{N} 1-\mathrm{C} 2-$ $\mathrm{C} 3-\mathrm{O} 1\left[73.7(2)^{\circ}\right]$ and $\mathrm{N} 1-\mathrm{C} 4-\mathrm{C} 5-\mathrm{O} 1\left[-53.9(2)^{\circ}\right]$ torsion angles, which span a range of approximately $20^{\circ}$ in (II) $c f$. approximately $12^{\circ}$ in (I). The molecular packing in (II) also features $\mathrm{O}-\mathrm{H} \cdots \mathrm{O}$ hydrogen and $\mathrm{O}-\mathrm{H} \cdots \mathrm{S}$ hydrogen bonding, as for (I), leading to a supramolecular layer; the intramolecular amine- $\mathrm{N}-\mathrm{H} \cdots \mathrm{O}$ (hydroxy) hydrogen bond persists. However, in the case of (II), there are directional interactions between layers, i.e. of the type phenyl-C$\mathrm{H} \cdots \pi$ (phenyl), to sustain a three-dimensional architecture. The other closely related structure is that of 4- $\left.\mathrm{MePhC}(=\mathrm{O}) \mathrm{N}(\mathrm{H}) \mathrm{C}(=\mathrm{S}) \mathrm{N}(\mathrm{Me}) \mathrm{CH}_{2} \mathrm{CH}_{2} \mathrm{OH}\right)$ (Jamaludin et al., 2016; refcode GADBOF). Here, the intramolecular amine- $\mathrm{N}-\mathrm{H} \cdots \mathrm{O}$ (hydroxy) hydrogen bond is also found and the most prominent feature of the molecular packing is the formation of supramolecular helical chains mediated by hydroxy-O $-\mathrm{H} \cdots \mathrm{O}$ (carbonyl) hydrogen bonds.

\section{Synthesis and crystallization}

All chemicals and solvents were used as purchased without purification. The reactions were carried out under ambient conditions. The melting point was measured using a Hanon MP-450 melting point apparatus. The CHN elemental analysis was performed on a LECO TruSpec Micro analyser under helium atmosphere with glycine being used as the standard. The IR spectrum was measured on a Bruker Vertex 70v FTIR spectrophotometer from 4000 to $400 \mathrm{~cm}^{-1}$. The ${ }^{1} \mathrm{H}$ and ${ }^{13} \mathrm{C}\left\{{ }^{1} \mathrm{H}\right\}$ spectra were recorded in DMSO- $d_{6}$ solutions on a Bruker Ascend $400 \mathrm{MHz}$ NMR spectrometer with chemical shifts relative to tetramethylsilane (TMS). The optical absorption spectra were measured on 10 and $100 \mu \mathrm{M}$ ethanol:acetonitrile (1:1) solutions in the range 190-1100 nm on a double-beam Shimadzu UV 3600 Plus UV-vis spectrophotometer. The thermogravimetric analysis (TGA) was performed on a Perkin Elmer STA 6000 Simultaneous Thermogravimetric Analyzer in the range of $35-900^{\circ} \mathrm{C}$ under a nitrogen atmosphere at a flow rate of $10^{\circ} \mathrm{C} \mathrm{min}^{-1}$. The experimental powder X-ray diffraction pattern was measured on a Rigaku MiniFlex diffractometer with $\mathrm{Cu} \mathrm{K} \alpha_{1}$ radiation $(\lambda$ $=1.54056 \AA$ ) in the $2 \theta$ range of $5-70^{\circ}$ and a step size of $0.02^{\circ}$.
The experimental PXRD patterns were compared to the simulated PXRD patterns calculated from the CIF using the Rigaku PDXL structure analysis software package. The patterns matched indicating that the reported crystal structure is representative of the bulk material.

Synthesis of (I): An excess of thionyl chloride (Merck) was mixed with 4-methylbenzoic acid (Merck, $1 \mathrm{mmol}$ ) and the resulting solution was refluxed until a pale-yellow solution was obtained. The excess thionyl chloride was removed on a water bath, leaving only 4-methylbenzoyl chloride, which is a yellow, viscous liquid. Ammonium thiocyanate (Fisher, $1 \mathrm{mmol}$ ) was added into an acetone $(30 \mathrm{ml})$ solution of 4-methylbenzoyl chloride $(1 \mathrm{mmol})$. The solution turned yellow after stirring for $2 \mathrm{~h}$. The white precipitate (ammonium chloride) was isolated upon filtration and to the yellow filtrate, bis(hydroxyethyl)amine (Acros, $1 \mathrm{mmol}$ ) was carefully added followed by stirring for $1 \mathrm{~h}$. Upon the addition of dichloromethane $(50 \mathrm{ml})$, a yellow precipitate was obtained, which was collected by filtration. Recrystallization from its hot acetone solution yielded colourless blocks after slow evaporation. White solid, yield $56 \%$, m.p. 400.3-402.1 K. Elemental analysis: $\mathrm{C}_{13} \mathrm{H}_{18} \mathrm{~N}_{2} \mathrm{O}_{3} \mathrm{~S}$, found (calculated): $\mathrm{C} 55.59$ (55.30), $\mathrm{H}$ 6.57 (6.43), N 9.79 (9.92). IR (ATR; $\left.\mathrm{cm}^{-1}\right)$ : $3312(b r, \nu \mathrm{OH})$, $3158(b r, v \mathrm{NH}), 3061\left(w, v \mathrm{CH}_{\text {aro }}\right), 2955-2881(w, v \mathrm{CH}), 1686$ $(s, \nu \mathrm{C}=\mathrm{O}), 1539(s, \nu \mathrm{C}=\mathrm{C}), 1250(s, \nu \mathrm{C}-\mathrm{N}), 1054(s, \nu \mathrm{C}=\mathrm{S})$, $747(s, \delta \mathrm{CH})$. UV (ethanol:acetonitrile; $5 \mathrm{ml}: 5 \mathrm{ml}): \lambda_{\max } \mathrm{nm}$ (assignment; $\log \varepsilon$ ) $354.4\left(n \rightarrow \pi^{*} ; 4.34\right), 294.0\left(n \rightarrow \pi^{*} ; 4.98\right)$, $246.4\left(\pi \rightarrow \pi^{*} ; 5.17\right), 202.6\left(\sigma \rightarrow \pi^{*} ; 5.17\right) .{ }^{1} \mathrm{H}$ NMR $(400 \mathrm{MHz}$, DMSO- $d_{6}$; see Fig. 1 for the numbering scheme): $\delta 10.78(1 \mathrm{H}$, $b r, s, \mathrm{NH}), 7.76\left(2 \mathrm{H}, d, 2\right.$-phenyl, $\left.{ }^{3} J_{\mathrm{HH}}=7.72 \mathrm{~Hz}\right), 7.31(2 \mathrm{H}, d$, 3-phenyl, $\left.{ }^{3} J_{\mathrm{HH}}=7.6 \mathrm{~Hz}\right), 5.66(1 \mathrm{H}, b r, s, \mathrm{OH}), 4.87(1 \mathrm{H}, t, \mathrm{OH}$, $\left.{ }^{3} J_{\mathrm{OH}-\mathrm{H}}=5.00 \mathrm{~Hz}\right), 3.98\left(2 \mathrm{H}\right.$, overlapping $t, \mathrm{CH}_{2}-\mathrm{C} 2,{ }^{3} J_{\mathrm{HH}}=$ $\left.6.24 \mathrm{~Hz},{ }^{3} J_{\mathrm{HH}}=6.08 \mathrm{~Hz}\right), 3.76\left(2 \mathrm{H}, m, \mathrm{CH}_{2}-\mathrm{C} 3\right), 3.70(4 \mathrm{H}, m$, $\left.\mathrm{CH}_{2}-\mathrm{C} 4, \mathrm{C} 5\right), 2.37\left(3 \mathrm{H}, s, \mathrm{CH}_{3}\right) .{ }^{13} \mathrm{C}\left\{{ }^{1} \mathrm{H}\right\}$ NMR $(100 \mathrm{MHz}$, DMSO- $d_{6}$ ): $\delta 180.63$ (C1), 163.78 (C6), 141.88 (C7), 130.13 (C10), 128.47 (C9, C11), 127.28 (C8, C12), 58.58 (C5), 56.95 (C3), 54.42 (C4), 54.29 (C2), 20.42 (C13).

The pyrolytic processes for (I) was resolved into four main stages. The first stage involves the liberation of $\mathrm{H}_{2} \mathrm{O}$ between 135 and $165^{\circ} \mathrm{C}$, which corresponds to approximate $6 \%$ of the weight for (I). The second stage between 160 and $240^{\circ} \mathrm{C}$ is attributed to the loss of a 4-methylbenzaldehyde fragment, corresponding to $45 \%$ weight loss. Subsequently, the remaining fragments undergo further pyrolysis to result in the liberation of ethanol (31\% weight) and ammonia (17-18\%) in the range 230 to $300^{\circ} \mathrm{C}$ and $300^{\circ} \mathrm{C}$ onward, respectively. Compound (I) decomposed at temperatures beyond $700^{\circ} \mathrm{C}$.

\section{Refinement}

Crystal data, data collection and structure refinement details are summarized in Table 7. Carbon-bound $\mathrm{H}$ atoms were placed in calculated positions $(\mathrm{C}-\mathrm{H}=0.93-0.97 \AA)$ and were included in the refinement in the riding-model approximation, with $U_{\text {iso }}(\mathrm{H})$ set to $1.2-1.5 U_{\text {eq }}(\mathrm{C})$. The $\mathrm{O}$ - and $\mathrm{N}$-bound $\mathrm{H}$ atoms were located from a difference map and refined with 
Table 7

Experimental details.

\begin{tabular}{|c|c|}
\hline \multicolumn{2}{|l|}{ Crystal data } \\
\hline Chemical formula & $\mathrm{C}_{13} \mathrm{H}_{18} \mathrm{~N}_{2} \mathrm{O}_{3} \mathrm{~S}$ \\
\hline$M_{\mathrm{r}}$ & 282.35 \\
\hline Crystal system, space group & Monoclinic, $P 2_{1} / c$ \\
\hline Temperature $(\mathrm{K})$ & 293 \\
\hline$a, b, c(\AA)$ & $\begin{array}{l}7.4051(10), 10.6213(15), \\
18.569(3)\end{array}$ \\
\hline$\beta\left(^{\circ}\right)$ & $94.117(2)$ \\
\hline$V\left(\AA^{3}\right)$ & $1456.7(4)$ \\
\hline$Z$ & 4 \\
\hline Radiation type & Мо $K \alpha$ \\
\hline$\mu\left(\mathrm{mm}^{-1}\right)$ & 0.23 \\
\hline Crystal size $(\mathrm{mm})$ & $0.12 \times 0.09 \times 0.08$ \\
\hline \multicolumn{2}{|l|}{ Data collection } \\
\hline Diffractometer & Bruker SMART APEX \\
\hline Absorption correction & $\begin{array}{l}\text { Multi-scan (SADABS; Sheldrick, } \\
\text { 1996) }\end{array}$ \\
\hline$T_{\min }, T_{\max }$ & $0.655,0.746$ \\
\hline $\begin{array}{l}\text { No. of measured, independent and } \\
\text { observed }[I>2 \sigma(I)] \text { reflections }\end{array}$ & $18125,3339,2263$ \\
\hline$R_{\text {int }}$ & 0.051 \\
\hline$(\sin \theta / \lambda)_{\max }\left(\AA^{-1}\right)$ & 0.650 \\
\hline \multicolumn{2}{|l|}{ Refinement } \\
\hline$R\left[F^{2}>2 \sigma\left(F^{2}\right)\right], w R\left(F^{2}\right), S$ & $0.039,0.098,1.04$ \\
\hline No. of reflections & 3339 \\
\hline No. of parameters & 182 \\
\hline No. of restraints & 3 \\
\hline $\mathrm{H}$-atom treatment & $\begin{array}{l}\mathrm{H} \text { atoms treated by a mixture of } \\
\text { independent and constrained } \\
\text { refinement }\end{array}$ \\
\hline$\Delta \rho_{\max }, \Delta \rho_{\min }\left(\mathrm{e} \AA^{-3}\right)$ & $0.17,-0.20$ \\
\hline
\end{tabular}

Computer programs: SMART and SAINT (Bruker, 2008), SHELXS97 (Sheldrick, 2008), SHELXL2014/7 (Sheldrick, 2015), ORTEP-3 for Windows (Farrugia, 2012), DIAMOND (Brandenburg, 2006) and publCIF (Westrip, 2010).

$\mathrm{O}-\mathrm{H}$ and $\mathrm{N}-\mathrm{H}=0.84 \pm 0.01$ and $0.88 \pm 0.01 \AA$, respectively, and with $U_{\text {iso }}(\mathrm{H})=1.5 \mathrm{U}_{\text {eq }}(\mathrm{O})$ and $1.2 U_{\text {eq }}(\mathrm{N})$.

\section{Funding information}

Crystallographic research at Sunway University is supported by Sunway University Sdn Bhd (grant No. STR-RCTRRCCM-001-2019).

\section{References}

Barolli, J. P., Maia, P. I. S., Colina-Vegas, L., Moreira, J., Plutin, A. M., Mocelo, R., Deflon, V. M., Cominetti, M. R., Camargo-Mathias, M. I. \& Batista, A. A. (2017). Polyhedron, 126, 33-41.

Bhattacharyya, S., Bhattacherjee, A., Shirhatti, P. R. \& Wategaonkar, S. (2013). J. Phys. Chem. A, 117, 8238-8250.

Binzet, G., Gumus, I., Dogen, A., Flörke, U., Kulcu, N. \& Arslan, H. (2018). J. Mol. Struct. 1161, 519-529.

Brandenburg, K. (2006). DIAMOND. Crystal Impact GbR, Bonn, Germany.

Bruker (2008). SMART and SAINT. Bruker AXS Inc., Madison, Wisconsin, USA.

Chai, J. D. \& Head-Gordon, M. (2008). Phys. Chem. Chem. Phys. 10, 6615-6620.

Contreras-García, J., Johnson, E. R., Keinan, S., Chaudret, R., Piquemal, J. P., Beratan, D. N. \& Yang, W. (2011). J. Chem. Theory Comput. 7, 625-632.

Cornejo, J. A., Ayala, K., Richter, R., Böhlig, H., Hennig, L. \& Beyer, L. (2005). Z. Anorg. Allg. Chem. 631, 3040-3045.
Cunha, S., Macedo, F. C., Costa, G. A. N., Rodrigues, M. T., Verde, R. B. V., de Souza Neta, L. C., Vencato, I., Lariucci, C. \& Sá, F. P. (2007). Monatsh. Chem. 138, 511-516.

Farrugia, L. J. (2012). J. Appl. Cryst. 45, 849-854.

Frisch, M. J., et al. (2016). Gaussian 16, Revision A. 03. Gaussian, Inc., Wallingford CT, USA.

Gemili, M., Sari, H., Ulger, M., Sahin, E. \& Nural, Y. (2017). Inorg. Chim. Acta, 463, 88-96.

Gunasekaran, N., Jerome, P., Ng, S. W., Tiekink, E. R. T. \& Karvembu, R. (2012). J. Molec. Catal. A: Chem. 353-354, 156-162.

Gunasekaran, N., Ng, S. W., Tiekink, E. R. T. \& Karvembu, R. (2012). Polyhedron, 34, 41-45.

Gunasekaran, N., Vadivel, V., Halcovitch, N. R. \& Tiekink, E. R. T. (2017). Chem. Data Coll. 9-10, 263-276.

Hallur, G., Jimeno, A., Dalrymple, S., Zhu, T., Jung, M. K., Hidalgo, M., Isaacs, J. T., Sukumar, S., Hamel, E. \& Khan, S. R. (2006). J. Med. Chem. 49, 2357-2360.

Jamaludin, N. S., Halim, S. N. A. \& Tiekink, E. R. T. (2016). IUCrData, 1, x152457.

Jelsch, C., Ejsmont, K. \& Huder, L. (2014). IUCrJ, 1, 119-128.

Jeyalakshmi, K., Haribabu, J., Balachandran, C., Narmatha, E., Bhuvanesh, N. S. P., Aoki, S., Awale, S. \& Karvembu, R. (2019). New J. Chem. 43, 3188-3198.

Johnson, E. R., Keinan, S., Mori-Sánchez, P., Contreras-García, J., Cohen, A. J. \& Yang, W. (2010). J. Am. Chem. Soc. 132, 64986506.

Koch, K. R., Sacht, C. \& Bourne, S. (1995). Inorg. Chim. Acta, 232, 109-115.

Macrae, C. F., Edgington, P. R., McCabe, P., Pidcock, E., Shields, G. P., Taylor, R., Towler, M. \& van de Streek, J. (2006). J. Appl. Cryst. 39, 453-457.

Nishikawa, T. (2018). Tetrahedron Lett. 59, 216-223.

Peng, B., Gao, Z., Li, X., Li, T., Chen, G., Zhou, M. \& Zhang, J. (2016). J. Biol. Inorg. Chem. 21, 903-916.

Petersson, G. A., Bennett, A., Tensfeldt, T. G., Al-Laham, M. A., Shirley, W. A. \& Mantzaris, J. (1988). J. Chem. Phys. 89, 2193-2218.

Plutín, A. M., Alvarez, A., Mocelo, R., Ramos, R., Castellano, E. E., da Silva, M. M., Colina-Vegas, L., Pavan, F. R. \& Batista, A. A. (2016). Inorg. Chem. Commun. 63, 74-80.

Reed, A. E., Curtiss, L. A. \& Weinhold, F. (1988). Chem. Rev. 88, 899926.

Saeed, A., Flörke, U. \& Erben, M. F. (2014). J. Sulfur Chem. 35, 318355.

Saeed, A., Larik, F. A., Jabeen, F., Mehfooz, H., Ghumro, S. A., ElSeedi, H. R., Ali, M., Channar, P. A. \& Ashraf, H. (2018). Russ. J. Gen. Chem. 88, 541-550.

Saeed, S., Rashid, N., Jones, P. G., Ali, M. \& Hussain, R. (2010). Eur. J. Med. Chem. 45, 1323-1331.

Selvakumaran, N., Karvembu, R., Ng, S. W. \& Tiekink, E. R. T. (2011). Acta Cryst. E67, o602.

Selvakumaran, N., Ng, S. W., Tiekink, E. R. T. \& Karvembu, R. (2011). Inorg. Chim. Acta, 376, 278-284.

Sheldrick, G. M. (1996). SADABS. University of Göttingen, Germany.

Sheldrick, G. M. (2008). Acta Cryst. A64, 112-122.

Sheldrick, G. M. (2015). Acta Cryst. C71, 3-8.

Tan, S. L., Jotani, M. M. \& Tiekink, E. R. T. (2019). Acta Cryst. E75, 308-318.

Turner, M. J., Mckinnon, J. J., Wolff, S. K., Grimwood, D. J., Spackman, P. R., Jayatilaka, D. \& Spackman, M. A. (2017). Crystal Explorer 17. The University of Western Australia.

Westrip, S. P. (2010). J. Appl. Cryst. 43, 920-925.

Woon, D. E. \& Dunning, T. H. Jr (1993). J. Chem. Phys. 98, 13581371.

Zhang, Z. \& Schreiner, P. R. (2009). Chem. Soc. Rev. 38, 1187-1198.

Zhang, Z.-J., Zeng, Y., Jiang, Z.-Y., Shu, B.-S., Sethuraman, V. \& Zhong, G.-H. (2018). Pest Manag. Sci. 74, 1736-1746. 


\section{supporting information}

Acta Cryst. (2019). E75, 1472-1478 [https://doi.org/10.1107/S2056989019012581]

\section{3,3-Bis(2-hydroxyethyl)-1-(4-methylbenzoyl)thiourea: crystal structure, Hirshfeld surface analysis and computational study}

Sang Loon Tan, Ainnul Hamidah Syahadah Azizan, Mukesh M. Jotani and Edward R. T. Tiekink

Computing details

Data collection: SMART (Bruker, 2008); cell refinement: SMART (Bruker, 2008); data reduction: SAINT (Bruker, 2008); program(s) used to solve structure: SHELXS97 (Sheldrick, 2008); program(s) used to refine structure: SHELXL2014/7 (Sheldrick, 2015); molecular graphics: ORTEP-3 for Windows (Farrugia, 2012), DIAMOND (Brandenburg, 2006); software used to prepare material for publication: publCIF (Westrip, 2010).

3,3-Bis(2-hydroxyethyl)-1-(4-methyllbenzoyl)thiourea

Crystal data

$\mathrm{C}_{13} \mathrm{H}_{18} \mathrm{~N}_{2} \mathrm{O}_{3} \mathrm{~S}$

$M_{r}=282.35$

Monoclinic, $P 2{ }_{1} / c$

$a=7.4051(10) \AA$

$b=10.6213(15) \AA$

$c=18.569(3) \AA$

$\beta=94.117(2)^{\circ}$

$V=1456.7(4) \AA^{3}$

$Z=4$

\section{Data collection}

Bruker SMART APEX diffractometer

Radiation source: fine-focus sealed tube Graphite monochromator $\varphi$ and $\omega$ scans

Absorption correction: multi-scan

(SADABS; Sheldrick, 1996)

$T_{\min }=0.655, T_{\max }=0.746$

Refinement

Refinement on $F^{2}$

Least-squares matrix: full

$R\left[F^{2}>2 \sigma\left(F^{2}\right)\right]=0.039$

$w R\left(F^{2}\right)=0.098$

$S=1.03$

3339 reflections

182 parameters

3 restraints

Primary atom site location: structure-invariant direct methods
$F(000)=600$

$D_{\mathrm{x}}=1.287 \mathrm{Mg} \mathrm{m}^{-3}$

Mo $K \alpha$ radiation, $\lambda=0.71073 \AA$

Cell parameters from 2509 reflections

$\theta=2.2-22.9^{\circ}$

$\mu=0.23 \mathrm{~mm}^{-1}$

$T=293 \mathrm{~K}$

Prism, colourless

$0.12 \times 0.09 \times 0.08 \mathrm{~mm}$

18125 measured reflections

3339 independent reflections

2263 reflections with $I>2 \sigma(I)$

$R_{\text {int }}=0.051$

$\theta_{\max }=27.5^{\circ}, \theta_{\min }=2.2^{\circ}$

$h=-9 \rightarrow 9$

$k=-13 \rightarrow 13$

$l=-24 \rightarrow 24$

Secondary atom site location: difference Fourier map

Hydrogen site location: mixed

$\mathrm{H}$ atoms treated by a mixture of independent and constrained refinement

$w=1 /\left[\sigma^{2}\left(F_{\mathrm{o}}^{2}\right)+(0.0374 P)^{2}+0.2262 P\right]$

where $P=\left(F_{\mathrm{o}}{ }^{2}+2 F_{\mathrm{c}}{ }^{2}\right) / 3$

$(\Delta / \sigma)_{\max }<0.001$

$\Delta \rho_{\max }=0.17$ e $\AA^{-3}$

$\Delta \rho_{\min }=-0.20$ e $\AA^{-3}$ 


\section{Special details}

Geometry. All esds (except the esd in the dihedral angle between two 1.s. planes) are estimated using the full covariance matrix. The cell esds are taken into account individually in the estimation of esds in distances, angles and torsion angles; correlations between esds in cell parameters are only used when they are defined by crystal symmetry. An approximate (isotropic) treatment of cell esds is used for estimating esds involving l.s. planes.

Fractional atomic coordinates and isotropic or equivalent isotropic displacement parameters $\left(\AA^{2}\right)$

\begin{tabular}{|c|c|c|c|c|}
\hline & $x$ & $y$ & $z$ & $U_{\text {iso }} * / U_{\text {eq }}$ \\
\hline S1 & $0.32019(6)$ & $0.58997(5)$ & $0.40517(3)$ & $0.05150(16)$ \\
\hline $\mathrm{O} 1$ & $0.20850(18)$ & $0.31841(13)$ & $0.20234(8)$ & $0.0600(4)$ \\
\hline $\mathrm{H} 1 \mathrm{O}$ & $0.239(3)$ & $0.2473(13)$ & $0.1888(13)$ & $0.090^{*}$ \\
\hline $\mathrm{O} 2$ & $-0.27874(16)$ & $0.58125(13)$ & $0.35097(7)$ & $0.0534(4)$ \\
\hline $\mathrm{H} 2 \mathrm{O}$ & $-0.3778(19)$ & $0.585(2)$ & $0.3699(11)$ & $0.080^{*}$ \\
\hline $\mathrm{O} 3$ & $0.37968(18)$ & $0.75187(12)$ & $0.26514(8)$ & $0.0602(4)$ \\
\hline N1 & $0.06795(17)$ & $0.47500(13)$ & $0.31953(7)$ & $0.0382(3)$ \\
\hline $\mathrm{N} 2$ & $0.31599(19)$ & $0.54248(13)$ & $0.26306(8)$ & $0.0402(3)$ \\
\hline $\mathrm{H} 2 \mathrm{~N}$ & $0.304(2)$ & $0.4767(12)$ & $0.2356(8)$ & $0.048^{*}$ \\
\hline $\mathrm{C} 1$ & $0.2270(2)$ & $0.53452(15)$ & $0.32668(9)$ & $0.0380(4)$ \\
\hline $\mathrm{C} 2$ & $-0.0239(2)$ & $0.44158(17)$ & $0.24885(10)$ & $0.0448(4)$ \\
\hline $\mathrm{H} 2 \mathrm{~A}$ & 0.0053 & 0.5045 & 0.2137 & $0.054^{*}$ \\
\hline $\mathrm{H} 2 \mathrm{~B}$ & -0.1537 & 0.4438 & 0.2528 & $0.054^{*}$ \\
\hline $\mathrm{C} 3$ & $0.0273(2)$ & $0.31392(18)$ & $0.22177(11)$ & $0.0524(5)$ \\
\hline $\mathrm{H} 3 \mathrm{~A}$ & 0.0155 & 0.2513 & 0.2592 & $0.063^{*}$ \\
\hline H3B & -0.0526 & 0.2907 & 0.1802 & $0.063^{*}$ \\
\hline $\mathrm{C} 4$ & $-0.0291(2)$ & $0.44025(17)$ & $0.38245(10)$ & $0.0456(4)$ \\
\hline $\mathrm{H} 4 \mathrm{~A}$ & 0.0583 & 0.4179 & 0.4218 & $0.055^{*}$ \\
\hline $\mathrm{H} 4 \mathrm{~B}$ & -0.1024 & 0.3664 & 0.3707 & $0.055^{*}$ \\
\hline $\mathrm{C} 5$ & $-0.1497(2)$ & $0.54346(19)$ & $0.40748(10)$ & $0.0497(5)$ \\
\hline $\mathrm{H} 5 \mathrm{~A}$ & -0.2125 & 0.5138 & 0.4483 & $0.060^{*}$ \\
\hline $\mathrm{H} 5 \mathrm{~B}$ & -0.0762 & 0.6153 & 0.4232 & $0.060^{*}$ \\
\hline C6 & $0.3952(2)$ & $0.64952(16)$ & $0.23710(9)$ & $0.0405(4)$ \\
\hline C7 & $0.4941(2)$ & $0.63211(16)$ & $0.17111(9)$ & $0.0393(4)$ \\
\hline $\mathrm{C} 8$ & $0.5608(2)$ & $0.51755(17)$ & $0.14953(9)$ & 0.0449 (4) \\
\hline H8 & 0.5419 & 0.4455 & 0.1764 & $0.054^{*}$ \\
\hline C9 & $0.6557(3)$ & $0.5097(2)$ & $0.08809(10)$ & $0.0562(5)$ \\
\hline H9 & 0.7011 & 0.4322 & 0.0747 & $0.067^{*}$ \\
\hline $\mathrm{C} 10$ & $0.6843(3)$ & $0.6145(2)$ & $0.04626(10)$ & $0.0584(5)$ \\
\hline C11 & $0.6157(3)$ & $0.7282(2)$ & $0.06798(11)$ & $0.0631(6)$ \\
\hline H11 & 0.6320 & 0.7999 & 0.0404 & $0.076^{*}$ \\
\hline $\mathrm{C} 12$ & $0.5241(3)$ & $0.73742(18)$ & $0.12945(11)$ & $0.0557(5)$ \\
\hline H12 & 0.4815 & 0.8154 & 0.1434 & $0.067^{*}$ \\
\hline $\mathrm{C} 13$ & $0.7870(4)$ & $0.6055(3)$ & $-0.02119(12)$ & $0.0919(9)$ \\
\hline $\mathrm{H} 13 \mathrm{~A}$ & 0.7224 & 0.6506 & -0.0598 & $0.138^{*}$ \\
\hline H13B & 0.7983 & 0.5187 & -0.0346 & $0.138^{*}$ \\
\hline $\mathrm{H} 13 \mathrm{C}$ & 0.9052 & 0.6416 & -0.0120 & $0.138^{*}$ \\
\hline
\end{tabular}


Atomic displacement parameters $\left(\AA^{2}\right)$

\begin{tabular}{lllllll}
\hline & $U^{11}$ & $U^{22}$ & $U^{33}$ & $U^{12}$ & $U^{13}$ & $U^{23}$ \\
\hline S1 & $0.0407(3)$ & $0.0703(4)$ & $0.0435(3)$ & $-0.0051(2)$ & $0.00312(19)$ & $-0.0119(2)$ \\
O1 & $0.0472(8)$ & $0.0542(9)$ & $0.0806(10)$ & $-0.0075(7)$ & $0.0181(7)$ & $-0.0248(7)$ \\
O2 & $0.0382(7)$ & $0.0691(9)$ & $0.0540(8)$ & $0.0084(6)$ & $0.0118(6)$ & $0.0126(7)$ \\
O3 & $0.0621(9)$ & $0.0393(8)$ & $0.0818(10)$ & $-0.0049(6)$ & $0.0227(7)$ & $-0.0135(7)$ \\
N1 & $0.0332(7)$ & $0.0397(8)$ & $0.0423(8)$ & $-0.0014(6)$ & $0.0059(6)$ & $-0.0025(6)$ \\
N2 & $0.0438(8)$ & $0.0378(8)$ & $0.0399(8)$ & $-0.0097(7)$ & $0.0093(6)$ & $-0.0063(6)$ \\
C1 & $0.0357(9)$ & $0.0356(9)$ & $0.0432(10)$ & $0.0024(7)$ & $0.0054(7)$ & $-0.0012(7)$ \\
C2 & $0.0370(9)$ & $0.0481(11)$ & $0.0487(10)$ & $-0.0027(8)$ & $-0.0003(8)$ & $-0.0064(8)$ \\
C3 & $0.0458(11)$ & $0.0512(12)$ & $0.0613(12)$ & $-0.0102(9)$ & $0.0114(9)$ & $-0.0150(9)$ \\
C4 & $0.0400(10)$ & $0.0482(11)$ & $0.0491(11)$ & $-0.0029(8)$ & $0.0068(8)$ & $0.0090(8)$ \\
C5 & $0.0430(10)$ & $0.0635(12)$ & $0.0435(10)$ & $-0.0005(9)$ & $0.0097(8)$ & $0.0033(9)$ \\
C6 & $0.0346(9)$ & $0.0376(10)$ & $0.0491(10)$ & $-0.0020(7)$ & $0.0019(8)$ & $-0.0023(8)$ \\
C7 & $0.0356(9)$ & $0.0400(10)$ & $0.0419(9)$ & $-0.0061(7)$ & $-0.0003(7)$ & $0.0023(7)$ \\
C8 & $0.0481(10)$ & $0.0430(10)$ & $0.0443(10)$ & $-0.0006(8)$ & $0.0073(8)$ & $0.0073(8)$ \\
C9 & $0.0598(13)$ & $0.0569(13)$ & $0.0530(12)$ & $0.0013(10)$ & $0.0121(10)$ & $-0.0038(10)$ \\
C10 & $0.0558(12)$ & $0.0773(16)$ & $0.0425(11)$ & $-0.0167(11)$ & $0.0067(9)$ & $0.0046(10)$ \\
C11 & $0.0703(14)$ & $0.0617(14)$ & $0.0577(13)$ & $-0.0171(11)$ & $0.0080(11)$ & $0.0206(11)$ \\
C12 & $0.0600(12)$ & $0.0422(11)$ & $0.0653(13)$ & $-0.0075(9)$ & $0.0076(10)$ & $0.0085(9)$ \\
C13 & $0.0952(19)$ & $0.126(2)$ & $0.0581(14)$ & $-0.0220(17)$ & $0.0303(14)$ & $0.0050(14)$ \\
& & & & & & \\
\hline
\end{tabular}

Geometric parameters $\left(A,{ }^{\circ}\right)$

\begin{tabular}{llll}
\hline $\mathrm{S} 1-\mathrm{C} 1$ & $1.6744(17)$ & $\mathrm{C} 4-\mathrm{H} 4 \mathrm{~B}$ & 0.9700 \\
$\mathrm{O} 1-\mathrm{C} 3$ & $1.415(2)$ & $\mathrm{C} 5-\mathrm{H} 5 \mathrm{~A}$ & 0.9700 \\
$\mathrm{O} 1-\mathrm{H} 1 \mathrm{O}$ & $0.832(9)$ & $\mathrm{C} 5-\mathrm{H} 5 \mathrm{~B}$ & 0.9700 \\
$\mathrm{O} 2-\mathrm{C} 5$ & $1.425(2)$ & $\mathrm{C} 6-\mathrm{C} 7$ & $1.483(2)$ \\
$\mathrm{O} 2-\mathrm{H} 2 \mathrm{O}$ & $0.836(9)$ & $\mathrm{C} 7-\mathrm{C} 8$ & $1.383(2)$ \\
$\mathrm{O} 3-\mathrm{C} 6$ & $1.214(2)$ & $\mathrm{C} 7-\mathrm{C} 12$ & $1.387(2)$ \\
$\mathrm{N} 1-\mathrm{C} 1$ & $1.335(2)$ & $\mathrm{C} 8-\mathrm{C} 9$ & $1.384(2)$ \\
$\mathrm{N} 1-\mathrm{C} 4$ & $1.462(2)$ & $\mathrm{C} 8-\mathrm{H} 8$ & 0.9300 \\
$\mathrm{~N} 1-\mathrm{C} 2$ & $1.477(2)$ & $\mathrm{C} 9-\mathrm{C} 10$ & $1.382(3)$ \\
$\mathrm{N} 2-\mathrm{C} 6$ & $1.382(2)$ & $\mathrm{C} 9-\mathrm{H} 9$ & 0.9300 \\
$\mathrm{~N} 2-\mathrm{C} 1$ & $1.396(2)$ & $\mathrm{C} 10-\mathrm{C} 11$ & $1.382(3)$ \\
$\mathrm{N} 2-\mathrm{H} 2 \mathrm{~N}$ & $0.866(9)$ & $\mathrm{C} 10-\mathrm{C} 13$ & $1.514(3)$ \\
$\mathrm{C} 2-\mathrm{C} 3$ & $1.504(2)$ & $\mathrm{C} 11-\mathrm{C} 12$ & $1.373(3)$ \\
$\mathrm{C} 2-\mathrm{H} 2 \mathrm{~A}$ & 0.9700 & $\mathrm{C} 11-\mathrm{H} 11$ & 0.9300 \\
$\mathrm{C} 2-\mathrm{H} 2 \mathrm{~B}$ & 0.9700 & $\mathrm{C} 12-\mathrm{H} 12$ & 0.9300 \\
$\mathrm{C} 3-\mathrm{H} 3 \mathrm{~A}$ & 0.9700 & $\mathrm{C} 13-\mathrm{H} 13 \mathrm{~A}$ & 0.9600 \\
$\mathrm{C} 3-\mathrm{H} 3 \mathrm{~B}$ & 0.9700 & $\mathrm{C} 13-\mathrm{H} 13 \mathrm{~B}$ & 0.9600 \\
$\mathrm{C} 4-\mathrm{C} 5$ & $1.508(3)$ & $\mathrm{C} 13-\mathrm{H} 13 \mathrm{C}$ & 0.9600 \\
$\mathrm{C} 4-\mathrm{H} 4 \mathrm{~A}$ & 0.9700 & & 109.4 \\
& & & 109.4 \\
$\mathrm{C} 3-\mathrm{O} 1-\mathrm{H} 1 \mathrm{O}$ & $109.1(18)$ & $\mathrm{C} 4-\mathrm{C} 5-\mathrm{H} 5 \mathrm{~A}$ & 109.4 \\
$\mathrm{C} 5-\mathrm{O} 2-\mathrm{H} 2 \mathrm{O}$ & $105.3(16)$ & $\mathrm{O} 2-\mathrm{C} 5-\mathrm{H} 5 \mathrm{~B}$ & \\
$\mathrm{C} 1-\mathrm{N} 1-\mathrm{C} 4$ & $121.39(14)$ & $\mathrm{C} 4-\mathrm{C} 5-\mathrm{H} 5 \mathrm{~B}$ & \\
& & &
\end{tabular}




\begin{tabular}{|c|c|c|c|}
\hline $\mathrm{C} 1-\mathrm{N} 1-\mathrm{C} 2$ & $123.27(14)$ & $\mathrm{H} 5 \mathrm{~A}-\mathrm{C} 5-\mathrm{H} 5 \mathrm{~B}$ & 108.0 \\
\hline $\mathrm{C} 4-\mathrm{N} 1-\mathrm{C} 2$ & $115.33(13)$ & $\mathrm{O} 3-\mathrm{C} 6-\mathrm{N} 2$ & $122.09(17)$ \\
\hline $\mathrm{C} 6-\mathrm{N} 2-\mathrm{C} 1$ & $125.67(14)$ & $\mathrm{O} 3-\mathrm{C} 6-\mathrm{C} 7$ & $122.23(16)$ \\
\hline $\mathrm{C} 6-\mathrm{N} 2-\mathrm{H} 2 \mathrm{~N}$ & $119.0(12)$ & $\mathrm{N} 2-\mathrm{C} 6-\mathrm{C} 7$ & $115.64(15)$ \\
\hline $\mathrm{C} 1-\mathrm{N} 2-\mathrm{H} 2 \mathrm{~N}$ & $114.6(12)$ & $\mathrm{C} 8-\mathrm{C} 7-\mathrm{C} 12$ & $118.21(17)$ \\
\hline $\mathrm{N} 1-\mathrm{C} 1-\mathrm{N} 2$ & $114.30(14)$ & $\mathrm{C} 8-\mathrm{C} 7-\mathrm{C} 6$ & $123.83(16)$ \\
\hline $\mathrm{N} 1-\mathrm{C} 1-\mathrm{S} 1$ & $123.97(13)$ & $\mathrm{C} 12-\mathrm{C} 7-\mathrm{C} 6$ & $117.95(16)$ \\
\hline $\mathrm{N} 2-\mathrm{C} 1-\mathrm{S} 1$ & $121.67(12)$ & $\mathrm{C} 7-\mathrm{C} 8-\mathrm{C} 9$ & $120.32(17)$ \\
\hline $\mathrm{N} 1-\mathrm{C} 2-\mathrm{C} 3$ & $113.76(15)$ & $\mathrm{C} 7-\mathrm{C} 8-\mathrm{H} 8$ & 119.8 \\
\hline $\mathrm{N} 1-\mathrm{C} 2-\mathrm{H} 2 \mathrm{~A}$ & 108.8 & $\mathrm{C} 9-\mathrm{C} 8-\mathrm{H} 8$ & 119.8 \\
\hline $\mathrm{C} 3-\mathrm{C} 2-\mathrm{H} 2 \mathrm{~A}$ & 108.8 & $\mathrm{C} 10-\mathrm{C} 9-\mathrm{C} 8$ & $121.45(19)$ \\
\hline $\mathrm{N} 1-\mathrm{C} 2-\mathrm{H} 2 \mathrm{~B}$ & 108.8 & $\mathrm{C} 10-\mathrm{C} 9-\mathrm{H} 9$ & 119.3 \\
\hline $\mathrm{C} 3-\mathrm{C} 2-\mathrm{H} 2 \mathrm{~B}$ & 108.8 & $\mathrm{C} 8-\mathrm{C} 9-\mathrm{H} 9$ & 119.3 \\
\hline $\mathrm{H} 2 \mathrm{~A}-\mathrm{C} 2-\mathrm{H} 2 \mathrm{~B}$ & 107.7 & $\mathrm{C} 11-\mathrm{C} 10-\mathrm{C} 9$ & $117.76(18)$ \\
\hline $\mathrm{O} 1-\mathrm{C} 3-\mathrm{C} 2$ & $108.71(15)$ & $\mathrm{C} 11-\mathrm{C} 10-\mathrm{C} 13$ & $120.9(2)$ \\
\hline $\mathrm{O} 1-\mathrm{C} 3-\mathrm{H} 3 \mathrm{~A}$ & 109.9 & $\mathrm{C} 9-\mathrm{C} 10-\mathrm{C} 13$ & $121.4(2)$ \\
\hline $\mathrm{C} 2-\mathrm{C} 3-\mathrm{H} 3 \mathrm{~A}$ & 109.9 & $\mathrm{C} 12-\mathrm{C} 11-\mathrm{C} 10$ & $121.24(19)$ \\
\hline $\mathrm{O} 1-\mathrm{C} 3-\mathrm{H} 3 \mathrm{~B}$ & 109.9 & $\mathrm{C} 12-\mathrm{C} 11-\mathrm{H} 11$ & 119.4 \\
\hline $\mathrm{C} 2-\mathrm{C} 3-\mathrm{H} 3 \mathrm{~B}$ & 109.9 & $\mathrm{C} 10-\mathrm{C} 11-\mathrm{H} 11$ & 119.4 \\
\hline $\mathrm{H} 3 \mathrm{~A}-\mathrm{C} 3-\mathrm{H} 3 \mathrm{~B}$ & 108.3 & $\mathrm{C} 11-\mathrm{C} 12-\mathrm{C} 7$ & $121.01(19)$ \\
\hline $\mathrm{N} 1-\mathrm{C} 4-\mathrm{C} 5$ & $113.48(14)$ & $\mathrm{C} 11-\mathrm{C} 12-\mathrm{H} 12$ & 119.5 \\
\hline $\mathrm{N} 1-\mathrm{C} 4-\mathrm{H} 4 \mathrm{~A}$ & 108.9 & $\mathrm{C} 7-\mathrm{C} 12-\mathrm{H} 12$ & 119.5 \\
\hline $\mathrm{C} 5-\mathrm{C} 4-\mathrm{H} 4 \mathrm{~A}$ & 108.9 & $\mathrm{C} 10-\mathrm{C} 13-\mathrm{H} 13 \mathrm{~A}$ & 109.5 \\
\hline $\mathrm{N} 1-\mathrm{C} 4-\mathrm{H} 4 \mathrm{~B}$ & 108.9 & $\mathrm{C} 10-\mathrm{C} 13-\mathrm{H} 13 \mathrm{~B}$ & 109.5 \\
\hline $\mathrm{C} 5-\mathrm{C} 4-\mathrm{H} 4 \mathrm{~B}$ & 108.9 & $\mathrm{H} 13 \mathrm{~A}-\mathrm{C} 13-\mathrm{H} 13 \mathrm{~B}$ & 109.5 \\
\hline $\mathrm{H} 4 \mathrm{~A}-\mathrm{C} 4-\mathrm{H} 4 \mathrm{~B}$ & 107.7 & $\mathrm{C} 10-\mathrm{C} 13-\mathrm{H} 13 \mathrm{C}$ & 109.5 \\
\hline $\mathrm{O} 2-\mathrm{C} 5-\mathrm{C} 4$ & $111.00(15)$ & $\mathrm{H} 13 \mathrm{~A}-\mathrm{C} 13-\mathrm{H} 13 \mathrm{C}$ & 109.5 \\
\hline $\mathrm{O} 2-\mathrm{C} 5-\mathrm{H} 5 \mathrm{~A}$ & 109.4 & $\mathrm{H} 13 \mathrm{~B}-\mathrm{C} 13-\mathrm{H} 13 \mathrm{C}$ & 109.5 \\
\hline $\mathrm{C} 4-\mathrm{N} 1-\mathrm{C} 1-\mathrm{N} 2$ & $169.93(14)$ & $\mathrm{O} 3-\mathrm{C} 6-\mathrm{C} 7-\mathrm{C} 8$ & $160.25(17)$ \\
\hline $\mathrm{C} 2-\mathrm{N} 1-\mathrm{C} 1-\mathrm{N} 2$ & $-11.1(2)$ & $\mathrm{N} 2-\mathrm{C} 6-\mathrm{C} 7-\mathrm{C} 8$ & $-22.1(2)$ \\
\hline $\mathrm{C} 4-\mathrm{N} 1-\mathrm{C} 1-\mathrm{S} 1$ & $-7.3(2)$ & $\mathrm{O} 3-\mathrm{C} 6-\mathrm{C} 7-\mathrm{C} 12$ & $-18.5(3)$ \\
\hline $\mathrm{C} 2-\mathrm{N} 1-\mathrm{C} 1-\mathrm{S} 1$ & $171.63(12)$ & $\mathrm{N} 2-\mathrm{C} 6-\mathrm{C} 7-\mathrm{C} 12$ & $159.18(16)$ \\
\hline $\mathrm{C} 6-\mathrm{N} 2-\mathrm{C} 1-\mathrm{N} 1$ & $133.37(17)$ & $\mathrm{C} 12-\mathrm{C} 7-\mathrm{C} 8-\mathrm{C} 9$ & $0.3(3)$ \\
\hline $\mathrm{C} 6-\mathrm{N} 2-\mathrm{C} 1-\mathrm{S} 1$ & $-49.3(2)$ & $\mathrm{C} 6-\mathrm{C} 7-\mathrm{C} 8-\mathrm{C} 9$ & $-178.41(16)$ \\
\hline $\mathrm{C} 1-\mathrm{N} 1-\mathrm{C} 2-\mathrm{C} 3$ & $89.8(2)$ & $\mathrm{C} 7-\mathrm{C} 8-\mathrm{C} 9-\mathrm{C} 10$ & $-0.9(3)$ \\
\hline $\mathrm{C} 4-\mathrm{N} 1-\mathrm{C} 2-\mathrm{C} 3$ & $-91.18(18)$ & $\mathrm{C} 8-\mathrm{C} 9-\mathrm{C} 10-\mathrm{C} 11$ & $0.4(3)$ \\
\hline $\mathrm{N} 1-\mathrm{C} 2-\mathrm{C} 3-\mathrm{O} 1$ & $-70.1(2)$ & $\mathrm{C} 8-\mathrm{C} 9-\mathrm{C} 10-\mathrm{C} 13$ & $-179.6(2)$ \\
\hline $\mathrm{C} 1-\mathrm{N} 1-\mathrm{C} 4-\mathrm{C} 5$ & $86.72(19)$ & $\mathrm{C} 9-\mathrm{C} 10-\mathrm{C} 11-\mathrm{C} 12$ & $0.7(3)$ \\
\hline $\mathrm{C} 2-\mathrm{N} 1-\mathrm{C} 4-\mathrm{C} 5$ & $-92.28(18)$ & $\mathrm{C} 13-\mathrm{C} 10-\mathrm{C} 11-\mathrm{C} 12$ & $-179.3(2)$ \\
\hline $\mathrm{N} 1-\mathrm{C} 4-\mathrm{C} 5-\mathrm{O} 2$ & $57.5(2)$ & $\mathrm{C} 10-\mathrm{C} 11-\mathrm{C} 12-\mathrm{C} 7$ & $-1.3(3)$ \\
\hline $\mathrm{C} 1-\mathrm{N} 2-\mathrm{C} 6-\mathrm{O} 3$ & $-6.8(3)$ & $\mathrm{C} 8-\mathrm{C} 7-\mathrm{C} 12-\mathrm{C} 11$ & $0.7(3)$ \\
\hline $\mathrm{C} 1-\mathrm{N} 2-\mathrm{C} 6-\mathrm{C} 7$ & $175.48(15)$ & $\mathrm{C} 6-\mathrm{C} 7-\mathrm{C} 12-\mathrm{C} 11$ & $179.56(18)$ \\
\hline
\end{tabular}

Hydrogen-bond geometry $\left(\hat{A},{ }^{\circ}\right)$

\begin{tabular}{lllll}
\hline$D-\mathrm{H} \cdots A$ & $D-\mathrm{H}$ & $\mathrm{H} \cdots A$ & $D \cdots A$ & $D-\mathrm{H} \cdots A$ \\
\hline $\mathrm{N} 2-\mathrm{H} 2 N \cdots \mathrm{O} 1$ & $0.87(1)$ & $1.91(1)$ & $2.728(2)$ & $157(1)$
\end{tabular}




$\begin{array}{lllll}\mathrm{O} 1-\mathrm{H} 1 O \cdots \mathrm{O} 2^{\mathrm{i}} & 0.83(2) & 1.94(2) & 2.769(2) & 172(2) \\ \mathrm{O} 2-\mathrm{H} 2 O \cdots \mathrm{S} 1^{\mathrm{ii}} & 0.84(2) & 2.38(2) & 3.2049(14) & 171(2) \\ \mathrm{C} 8-\mathrm{H} 8 \cdots 3^{\mathrm{iii}} & 0.93 & 2.38 & 3.251(2) & 156\end{array}$

Symmetry codes: (i) $-x, y-1 / 2,-z+1 / 2$; (ii) $x-1, y, z$; (iii) $-x+1, y-1 / 2,-z+1 / 2$. 